\title{
TRANSITIONS FROM HIGHER EDUCATION TO LABOUR MARKET: OBSERVATORY OF INTERNSHIPS IN BUSINESS ORGANIZATIONS
}

\author{
M. Magalhães ${ }^{1}$, P. Morais ${ }^{1}$, F. Lopes ${ }^{1}$, I. Freitas ${ }^{1}$, S. Fernandes ${ }^{2}$, C. Costa Lobo ${ }^{2}$ \\ ${ }^{1}$ Universidade Portucalense (PORTUGAL) \\ ${ }^{2}$ Instituto de Neuropsicologia e Neurociências Cognitiva e Comportamental Portucalense \\ (INPP) / Universidade Portucalense (PORTUGAL)
}

\begin{abstract}
The main objective of the present study is to present a proposal for an observatory based on the impact of Curricular Internships in business organizations, internships in higher education, with the overall goal to provide a better understanding of the transition process of students from higher education to the labour market. In this paper, besides the bibliographical revision carried out, preliminary results from an ongoing empirical study carried out with students enrolled in the Management Bachelor degree at the Portucalense University, Portugal, will be presented. This study aims to provide evidence for the development of an Observatory based on the impact of student curricular Internships in business organizations. Data collection was based on the analysis of results from student evaluations achieved in the Internship course, in the academic years of 2014/15 and 2015/16, of the Management degree at UPT. For this, the evaluation results of students provided by the Curricular Internship Advisor, through an Evaluation Form completed at the end of the internship (evaluation criteria focus mainly on the assessment of transversal competences) and the evaluation results based on student's final grade achieved in the internship course (as a result of the evaluation of the internship report, its presentation and public discussion), were considered. Based on the statistical analysis carried out, results show that the average results obtained in both academic years are very similar. In 2014/15, the average evaluation was of 4.4 points, while in 2015/16 the average achieved was 4.5 points, based on a five-point Likert scale. Findings obtained from this Observatory contribute to widen the analysis of its effectiveness in terms of future research and actions in regard to the transition of Higher Education pathways to the Labour Market.
\end{abstract}

Keywords: curricular internships, management bachelor programme, observatory.

\section{INTRODUCTION}

Designing the process of transition to working life as the construction and implementation of a single and large life project, more or less linear, is not congruent with the current rapid reconfiguration of professions. Academic training does not constitute an accurate predictor in the construction of the next professional incarnations, nor does it allow one to assume the future levels of professional competence of higher education graduates. There are few learning experiences in a work context during a course degree, which makes it difficult to understand how the labour market works, what is expected of young people in a professional context, what skills they need to develop, as well as learn what skills are necessary and valued in their area of expertise [1], [2], [3], [4],, [5], [6], [7]._These aspects are related to the difficulties in the transition to the labour market identified both by employers and by young people - the difficulty in adapting to the hierarchical structure of companies, in understanding what is their role within and demystifying their expectations on tasks they feel able to do and/or hoping to make and those they really are assigned to do [1], [2], [3], [4], [5], [8], [9]. The relationships between teaching and the subsequent insertion in the professional world, configures two nuclear aspects: on the one hand, the training provided, and on the other, the impact on the professional activities to be performed. The main objective of the present study is to present a proposal for an observatory based on the impact of Curricular internships in business organizations, internships in higher education, with the overall goal to provide a better understanding of the transition process of students from higher education to the labour market. The present work presents a research on a current problem.

\section{FROM HIGHER EDUCATION TO LABOUR MARKET}

The research carried out over the last eighty years on the issue of "school-labour market transition" has been emphasizing the importance of looking at the preparation of higher education for work in a 
developmental perspective [7]. In this context, the anticipatory activities are among the most recommended. These are activities geared to knowledge and understanding of the labour market and to the development of attitudes and exploration and planning skills that enable students to anticipate, become aware, to explore, to become involved, to become familiar and plan their professional development tasks, encouraging them to consider to what extent they are able to handle those tasks and what they still need to think and do for the purpose. The teaching of cognitive and behavioral skills to advance schooling and the world of paid work is another important intervention strategy, involving, for example, teaching the similarities and differences between school and employment, teaching to cope with the clash culture and climate of the new work environment. Training in career management techniques and role-testing are two other types of intervention strategies recommended in preparing graduates for the transition to the labour market [7]. It is about providing learning and developing personal ways in terms of practical intelligence, dealing with your career, dealing with co-workers, and also dealing with employers' social expectations, changes in his career, among others [10]. Or, offer opportunities for the simulation and experimentation of roles designed to prepare students to solve everyday problems in employment [8]. The main purpose of the University in this field is no longer to help students choose or decide what they want to be or to become, to help students learn the skills they need to become healthy, confident and capable citizens to deal effectively with labour market transitions and to maintain the balance between work, education and the family in a world of greater change [8].The transition to the labour market is seen as an element of vocational development which is characterized by a long process in time, which begins before the conclusion of graduation courses and that continues even after the beginning of the labour activity [6].

\subsection{Graduate employability: matching professional preferences}

The adaptive transition from university to employment is determined according to each internal psychological dimension, job satisfaction and matching professional preferences [1], [2], [3], [4], [5], [6], [7], [8], [9], [10], [11], [12]. Employability can be seen as a set of competencies and skills necessary for a person to get and keep a job [1], [2], [6], [12], in which it is believed that the individual is the only one responsible for his/her own career and professional path. At 2013 was created [13] the USEM model (understanding, skillful practices, efficacy beliefs and meta-cognition), which identifies four factors that influence employability: (a) understanding (knowledge of the course units subjects important in the assessment of a course degree); (b) skillful practices (skills based on the awareness of the context and the ability to respond to it); (c) efficacy beliefs (beliefs about oneself and the ability to be effective when faced with new challenges); and (d) meta-cognition (awareness of how an individual learns, ability to reflect on and about a situation and ability to self-regulate). At 2008 was suggested [14] a new five-dimensional model, which they consider critical and representative of the active and adaptable nature of the dispositional employability: openness to changes at work; work and career resilience; work and career proactivity; career motivation and work identity. The soft skills that young people possess can facilitate their transition to the labour market. According to [15], the skills chosen by employers as the most important for professional purposes in the first five years are: analysis and problem solving, creativity and innovation, adaptability and flexibility, planning and organization, motivation for excellence. Some suggestions and intervention strategies that could be implemented with higher education students are: to improve communication between teachers and students in order to build more and better supports and academic resources; create psychoeducational interventions to boost academic self-efficacy and outcome expectations; psychological counseling; increase the level of practical experiences provided to young people during their academic career (e.g. job shadowing programs); help to identify the strengths and weaknesses of each individual in order to implement skill development techniques directed towards the real and personal needs of young people; creation of programs with the purpose of mentoring, coaching and talent development, and personal and social skills supports within and outside the education system.

\subsection{Observatory of Internships}

Increasingly, the link between universities and society through the transfer of knowledge and cultural influence requires well-defined strategies, articulated with the various dimensions of the university's mission. An observatory of the internships can be a powerful instrument for the definition of the University's strategy, namely with regard the curriculum plans design and the connection to society or to the region, both in terms of training in study cycles and of teachers activity. In addition, the observatory of internships is relevant because of the ambition to be able to support the understanding of the extent to which the design of the study cycle, especially in the first cycle, will have to cover different dimensions of the training and how should it position them in order to prepare the young 
people, rather than for specific professions, for future professional performances that will not be linear. In other words, the Observatory of Internships in Higher Education has the great relevance of ensuring the development of competences and capacities that, based on high quality education, prepare and enable the students of higher education to meet the challenges or employment market constraints and to take advantage of lifelong learning opportunities.

In this context, the creation of an Observatory of Internships at the Portucalense University aims to guide its contribution not only for a solid knowledge of the practices of its students in the labour context, but also for the definition of strategic lines of development and the quality of the training. This vision required the approval of a methodology that would achieve the desired ends.

\section{CONTEXT OF THE STUDY}

Portucalense University (UPT), is a private higher education institution, ISO 9001 certified, recognized by the Portuguese Government and the Portuguese Agency for Assessment and Accreditation of Higher Education - A3ES. Created in June of 1986, UPT - Oporto Global University is located in Oporto, in the north of Portugal. Oporto is the country's second largest city situated within an urban area of over 1.3 million inhabitants. Its historical center has been a UNESCO World Heritage Site since 1996. The city of Oporto is also a center of educational and research excellence, standing out for its technological and scientific innovation which attracts students from all across the country and from overseas. UPT is organized in four Departments: Law; Economics, Management and Informatics; Heritage and Tourism; and Psychology and Education, Departments that teach 1st and 2nd cycle programs and post graduations, structured according to the Bologna Process. UPT aims to be a model in higher education, taking the advantages of the different department's synergies. More than acquiring theoretical knowledge, the students have the chance to develop practical work and research projects, developing different kinds of skills that prepare them for jobs in future career and for living in a competitive global society. Courses are structured so as to respond flexibly to changing labour market needs, through various teaching methods empirically based on significant case studies whenever applicable. UPT has its own dedicated staff, fully qualified, research-active and highly motivated by a spirit of constant self-improvement. It also counts on the input of practicing professionals from different industrial and commercial sectors, through the medium of guest seminars on various themes, thereby promoting its relationships with the corporate world with the goal of preparing students for future professional demands.

\subsection{Management Programme}

The UPT has been running its Bachelor of Science in Management for nearly three decades now, having thrown into the market thousands of managers that today secure key positions in business, finance, or public administration. This degree covers a full range of curricular units so as to provide a broad and integrated understanding of the main business functional areas in a modern fast-changing global environment. Ongoing attentiveness and responsiveness to the needs of todays' organizations have led the UPT management programme to undergo a number of changes over the past decades in order to build a legacy of strong and cutting-edge foundation of management knowledge. To earn the Bachelor of Science in Management students must complete a total of 180 ECTS (cf. Table 1). Most students take 30 credits per semester, which means they will have completed their degree in three years. The later year of the programme offers the option of optional modules so as to enhance career prospects according to individual interests. It also includes a work placement which is an opportunity to get hands-on experience of the types of challenges faced in the business world. This work placement, known as the internship course, will be described with greater depth in the next section. This paper will focus mainly on the analysis of the impact of these internships for business organizations. 
Table 1. Study Plan of Bachelor degree in Management

\begin{tabular}{|c|c|c|c|}
\hline COURSE UNIT & ECTS & COURSE UNIT & ECTS \\
\hline $1^{\text {st }}$ year, $1^{\text {st }}$ semester & & $1^{\text {st }}$ year, $2^{\text {nd }}$ semester & \\
\hline General Accounting & 6 & Financial Accounting & 5 \\
\hline Mathematics & 6 & Information and Knowledge Society & 3 \\
\hline $\begin{array}{l}\text { Economics and Management Analysis } \\
\text { Techniques }\end{array}$ & 4 & Microeconomic Analysis of Markets & 6 \\
\hline Corporate Organization & 5 & Corporate Planning & 5 \\
\hline Microeconomics & 6 & Statistics & 5 \\
\hline Economic Law & 3 & Macroeconomics & 6 \\
\hline $2^{\text {nd }}$ year, $1^{\text {st }}$ semester & & $2^{\text {nd }}$ year, $2^{\text {nd }}$ semester & \\
\hline Corporate Finance & 5 & Financial Markets & 5 \\
\hline Taxation Law & 4 & Management Accounting & 4 \\
\hline Analytical Accounting & 5 & Financial and Project Analysis & 6 \\
\hline Industrial Economics and Regulation & 5 & Taxation & 4 \\
\hline Monetary and Financial Economics & 5 & International Finance & 5 \\
\hline Quantitative Methods & 6 & International Business Management & 5 \\
\hline $3^{\text {rd }}$ year, $1^{\text {st }}$ semester & & $3^{\text {rd }}$ year, $2^{\text {nd }}$ semester & \\
\hline Marketing & 5 & Management Control & 5 \\
\hline Human Resources Management & 5 & $\begin{array}{l}\text { Innovation Economics and } \\
\text { Management }\end{array}$ & 5 \\
\hline Strategic Management & 5 & Commercial Management & 5 \\
\hline Entrepreneurship & 5 & Traineeship & 10 \\
\hline Management Information Systems & 5 & Optional Curricular Units & 5 \\
\hline Optional Curricular Units & 5 & Management Control & 5 \\
\hline
\end{tabular}

\subsubsection{Internship Course}

Imminently practical, this curricular unit is carried out through the implementation of projects in a work context, with individual orientation sessions and tutorial support sessions being promoted. The tutorial sessions, led by the supervisor of the internship, individualized follow-up for each student, aim to clarify doubts and guide the execution of a project in one of the management areas.

This course aims to: apply in the work context the knowledge acquired during the previous semesters, develop the capacity to research and analyze the main aspects related to the reality of the organization, promote the intersection of the fundamental themes to overcome the challenges that arise to organizational managers, to recognize, articulate and integrate management practices and methodologies, to motivate the implementation of the technical concepts acquired in the decisionmaking process circuit, and to prepare a report on the activities and projects developed.

The Table 2 presents the steps and procedures related to these tasks. 
Table 2. Steps, Participants and Procedures involved in the Internship Process

\begin{tabular}{|c|c|c|c|}
\hline Steps & Task & Procedure(s) & Participants \\
\hline \multirow[t]{3}{*}{1} & \multirow{3}{*}{$\begin{array}{l}\text { Student } \\
\text { Preference } \\
\text { Survey }\end{array}$} & $\begin{array}{l}\text { - Indication of the area and place of preference for } \\
\text { curricular internship. }\end{array}$ & $\begin{array}{l}\text { - Internship Coordinating Council } \\
\text { (CCE) }\end{array}$ \\
\hline & & $\begin{array}{l}\text { - Option of the typology of the curricular internship: PT } \\
\text { part-time / FT full-time. }\end{array}$ & $\begin{array}{l}\text { - Curricular internship student } \\
\text { (AEC) }\end{array}$ \\
\hline & & $\begin{array}{l}\text { - Collection of students CV after a workshop on CV } \\
\text { preparation. }\end{array}$ & \\
\hline \multirow[t]{4}{*}{2} & \multirow[t]{4}{*}{$\begin{array}{l}\text { Company } \\
\text { Procurement }\end{array}$} & \multirow{2}{*}{$\begin{array}{l}\text { - Identification of the organizations that correspond to } \\
\text { the area, place and typology (PT / FT) of preference } \\
\text { for the curricular internship. }\end{array}$} & $\begin{array}{l}\text { - Internship Coordinating Council, } \\
\text { UPT (CCE) }\end{array}$ \\
\hline & & & - Welcoming trainees Organization \\
\hline & & - Internship regulations are sent to the organization. & $(\mathrm{LAO})$ \\
\hline & & $\begin{array}{l}\text { - Short list of organizations segmented by area, } \\
\text { location and type of internship. }\end{array}$ & \\
\hline \multirow[t]{8}{*}{3} & \multirow{8}{*}{$\begin{array}{l}\text { Organizational } \\
\text { Philosophy of } \\
\text { Curricular } \\
\text { Internship }\end{array}$} & \multirow{3}{*}{$\begin{array}{l}\text { - Student CV is sent to the organizations to plan an } \\
\text { interview and select the student. } \\
\text { - Appointment of the curricular internship advisor and } \\
\text { supervisor, after approval of the student CV by the } \\
\text { organization. }\end{array}$} & $\begin{array}{l}\text { - Direction of the Department of } \\
\text { Economics, Management and }\end{array}$ \\
\hline & & & Informatics \\
\hline & & & $\begin{array}{l}\text { - Welcoming trainees Organization } \\
\text { (LAO) }\end{array}$ \\
\hline & & \multirow{2}{*}{$\begin{array}{l}\text { - At the first internship meeting, the protocol will be } \\
\text { presented and the objectives of the internship will be } \\
\text { explained. }\end{array}$} & $\begin{array}{l}\text { - Internship Coordinating Council, } \\
\text { UPT (CCE) }\end{array}$ \\
\hline & & & - Curricular internship advisor \\
\hline & & \multirow{3}{*}{$\begin{array}{l}\text { - Assignment of the project to the student and } \\
\text { definition of the respective planning (gantt chart). }\end{array}$} & $(\mathrm{OEC})$ \\
\hline & & & $\begin{array}{l}\text { - Curricular internship student } \\
\text { (AEC) }\end{array}$ \\
\hline & & & $\begin{array}{l}\text { - Curricular internship supervisor } \\
\text { (SEC) }\end{array}$ \\
\hline \multirow[t]{6}{*}{4} & \multirow{6}{*}{$\begin{array}{l}\text { Internship } \\
\text { Project }\end{array}$} & \multirow{2}{*}{$\begin{array}{l}\text { - Signing of the internship protocol between the } \\
\text { organization and the UPT. }\end{array}$} & Core of internship: \\
\hline & & & - Curricular internship advisor \\
\hline & & \multirow{2}{*}{$\begin{array}{l}\text { - Development of the curricular internship project } \\
\text { under the OEC orientation (practical implementation } \\
\text { of the project) and supervision by the SEC (theoretical } \\
\text { framework of the project). }\end{array}$} & $(\mathrm{OEC})$ \\
\hline & & & $\begin{array}{l}\text { - Curricular internship student } \\
\text { (AEC) }\end{array}$ \\
\hline & & $\begin{array}{l}\text { - Note whether there are deviations in the project from } \\
\text { the objectives and tasks carried out in relation to the } \\
\text { planned. }\end{array}$ & $\begin{array}{l}\text { - Curricular internship supervisor } \\
\text { (SEC) }\end{array}$ \\
\hline & & $\begin{array}{l}\text { - Realign the project, if necessary, taking into account } \\
\text { the organization's initial objectives and expectations. }\end{array}$ & \\
\hline \multirow[t]{4}{*}{5} & \multirow[t]{4}{*}{$\begin{array}{l}\text { Internship } \\
\text { Report }\end{array}$} & \multirow{2}{*}{$\begin{array}{l}\text { - The SEC guarantees that the writing of the } \\
\text { internship report complies with the guidelines pre- } \\
\text { defined by the Internship Coordinating Council of UPT } \\
\text { (CCE). }\end{array}$} & $\begin{array}{l}\text { - Curricular internship advisor } \\
\text { (OEC) }\end{array}$ \\
\hline & & & $\begin{array}{l}\text { - Curricular internship student } \\
\text { (AEC) }\end{array}$ \\
\hline & & \multirow{2}{*}{$\begin{array}{l}\text { - The OEC ensures that the writing of the internship } \\
\text { report fulfils the objectives and initial expectations of } \\
\text { the OAE organization. } \\
\text { - The CCE evaluates and approves the report. }\end{array}$} & $\begin{array}{l}\text { - Curricular internship supervisor } \\
\text { (SEC) }\end{array}$ \\
\hline & & & $\begin{array}{l}\text { - Internship Coordinating Council } \\
\text { (CCE) }\end{array}$ \\
\hline \multirow[t]{6}{*}{6} & \multirow{6}{*}{$\begin{array}{l}\text { Evaluation of } \\
\text { the Internship } \\
\text { Report }\end{array}$} & \multirow{2}{*}{$\begin{array}{l}\text { - The student submits the report to the CCE and } \\
\text { requests the marking of the oral defense test made up } \\
\text { of } 3 \text { elements (SEC, OEC and CCE). }\end{array}$} & $\begin{array}{l}\text { - Curricular internship advisor } \\
\text { (OEC) }\end{array}$ \\
\hline & & & - Curricular internship student \\
\hline & & \multirow{2}{*}{$\begin{array}{l}\text { - OEC assigns a qualitative evaluation on a likert } \\
\text { scale of } 5 \text { points, according to } 12 \text { evaluation and } \\
\text { performance criteria. }\end{array}$} & $(\mathrm{AEC})$ \\
\hline & & & $\begin{array}{l}\text { - Curricular internship supervisor } \\
\text { (SEC) }\end{array}$ \\
\hline & & $\begin{array}{l}\text { - The ECC critically evaluates the report proposing } \\
\text { suggestions for continuous improvement and good } \\
\text { practices of the curricular trainee projects to the OEC. }\end{array}$ & $\begin{array}{l}\text { - Internship Coordinating Council } \\
\text { (CCE) }\end{array}$ \\
\hline & & $\begin{array}{l}\text { - The SEC and the CCE quantitatively evaluate the } \\
\text { student's report and oral test from } 0 \text { to } 20 \text { values. }\end{array}$ & \\
\hline
\end{tabular}




\subsubsection{Evaluation of the Internship Course}

The evaluation of the Internship course, within the scope of the UPT management degree, is based on results from:

the qualitative evaluation carried out by the Curricular Internship Advisor, who is responsible for assigning a classification on a likert scale of five points, according to 12 evaluation criteria (see Table 4);

the quantitative evaluation of the internship report, including its presentation and public discussion, with an evaluation panel designated for that purpose, where the following formula is applied: $(60 \% \times A)+(20 \% \times B)+(20 \% \times C)$. Being:

A: Internship Report, whose score, between 0 and 20, results from the application of the following evaluation criteria: compliance with the editing guidelines - $10 \%$, graphic quality $-10 \%$, structure of the report - $10 \%$, clarity of information $-10 \%$, Subject approach - $40 \%$, quality of the bibliographical references $-10 \%$ and originality $-10 \%$.

B: Quantitative evaluation carried out by the Internship Coordinating Council .

C: Quantitative evaluation performed by the Curricular Internship Advisor.

\section{METHODOLOGY}

In this article, besides the bibliographical revision carried, it is also possible to present and disseminate preliminary results from an ongoing empirical study carried out with students enrolled in the curricular unit described above. For this analysis, results from student evaluations achieved in the Internship course, in the academic years of 2014/15 and 2015/16, of the Management degree at UPT, were analyzed. Data collection was based on a document analysis of the following information: evaluation results of students provided by the Curricular Internship Advisor, through an Evaluation Form completed at the end of the internship (evaluation criteria focus mainly on the assessment of transversal competences); evaluation results based on student's final grade achieved in the internship course (as a result of the evaluation of the internship report, its presentation and public discussion).

In regard to the characterization of the participants included in the study (cf. Table 3), the population size was 87 students enrolled in the course, 35 of whom attended the course in the 2014/15 school year and 52 attended the same course in the 2015/16 school year. The criterion for inclusion in the studied sample was to have no more than two curricular units of the study plan of the degree of management in arrears. There was a sample size of 69 students $(79.3 \%), 24$ in the 2014/15 school year $(68.6 \%)$ and 45 in the $2015 / 16$ school year $(86.5 \%)$.

Table 3. Population and sample sizes

\begin{tabular}{ccccc}
\hline $\begin{array}{c}\text { Academic } \\
\text { year }\end{array}$ & population size & $\begin{array}{c}\text { does not meet } \\
\text { requirements }\end{array}$ & \multicolumn{2}{c}{ sample size } \\
$\mathbf{2 0 1 4 / 1 5}$ & 35 & 11 & 24 & $68.6 \%$ \\
$\mathbf{2 0 1 5 / 1 6}$ & 52 & 07 & 45 & $86.5 \%$ \\
TOTAL & $\mathbf{8 7}$ & $\mathbf{1 8}$ & $\mathbf{6 9}$ & $\mathbf{7 9 . 3} \%$ \\
\hline
\end{tabular}

\section{RESULTS}

From the statistical analysis carried out, concerning the evaluation carried out by Curricular Internship Advisor, based on the classification of a five-point likert scale, the average results obtained in the academic years of 2014/15 and 2015/16 are very similar, as shown on Table 4. In 2014/15, the average evaluation was of 4.4 points, while in 2015/16 the average achieved was 4.5 points. 
Table 4. Evaluation carried out by Curricular Internship Advisor

\begin{tabular}{lccc}
\hline Rating criterial Curricular Internship Advisor & $\begin{array}{c}\text { School year } \\
\mathbf{2 0 1 4 / 1 5}\end{array}$ & $\begin{array}{c}\text { School year } \\
\mathbf{2 0 1 5 / 1 6}\end{array}$ & Evolution \\
\hline 1. Motivation and interest in the activities developed & 4.6 & 4.7 & +0.1 \\
2. Interpersonal relationship & 4.5 & 4,6 & +0.1 \\
3. Cooperation in the activities of the company & 4.4 & 4.7 & +0.3 \\
4. Assiduity & 4.8 & 4.7 & -0.1 \\
5. Ease of seizure of knowledge & 4.5 & 4.4 & -0.1 \\
6. Compliance with standards & 4.8 & 4.8 & 0 \\
7. Insertion into the work environment & 4.6 & 4.6 & 0 \\
8. Productivity & 4.3 & $4-4$ & +0.1 \\
9. Initiative & 4.3 & 4.1 & -0.2 \\
10. Ability to take on responsibilities & 4.3 & 4.3 & 0 \\
11. Creativity in proposing solutions & 4.1 & 4.0 & -0.1 \\
12. Self-confidence & 4.2 & 4.1 & -0.1 \\
Average & 4.4 & 4.5 & $\mathbf{+ 0 . 1}$ \\
\hline
\end{tabular}

The final classification of the students who attended the course unit, in the scope of the UPT management degree, in both school years in analysis, was, on average, 17.1 values. The assignment of this final classification, as set out above, results from the public discussion of the internship report before an evaluation panel appointed for this purpose, consisting of three elements: an element of the traineeship coordinator, the supervisor and the advisor of the student.

Pearson's correlation coefficient was used to study the relationship between the qualitative assessment, attributed by the Curricular Internship Advisor and the final grade awarded by the evaluation panel, obtaining in the 2014/15 school year a median positive correlation (0.61), while in the academic year 2015/16, a strong positive correlation (0.78) was obtained.

Fig. 1 represents the proposed observatory of Internships, which is contextualized and analysed here.

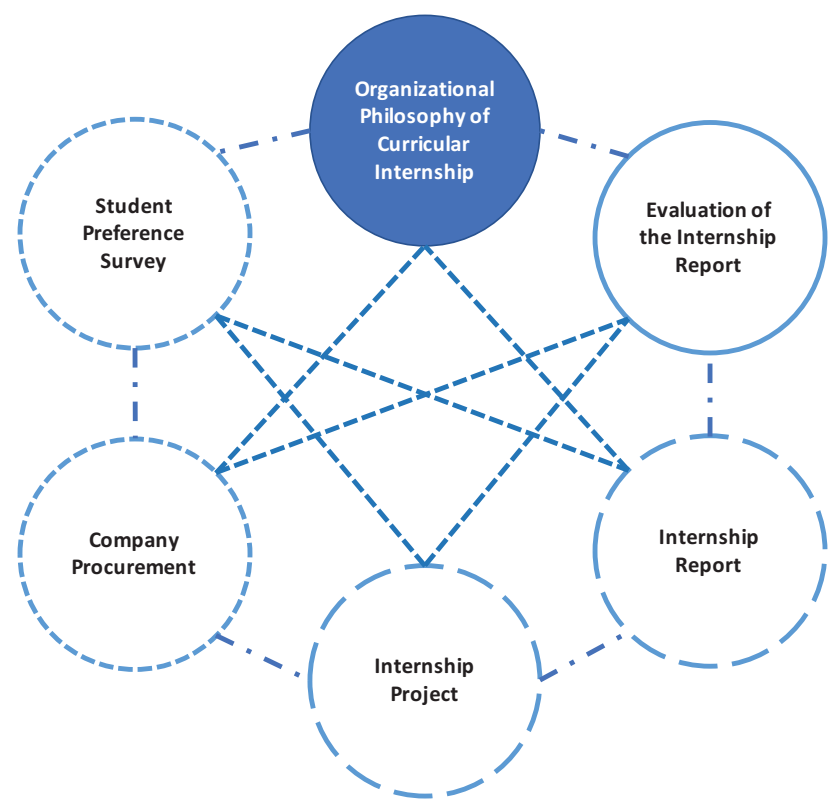

Figure 1: UPT Proposed Observatory of Internships

\section{FINAL REMARKS}

The curricular internship represents the first opportunity for an integrated application of all the student's knowledge, as well as the beginning of continuous self-training, as well as being the first 
contact with the reality of the world of work for a large number of undergraduate students. During the internship, training course with a minimum duration of 270 hours, but which may be extended according to the project objective that the trainee will have to develop up to a maximum of six months, the future license evidences his professional attitude to the future activity in the labour market and demonstrates, in the labour practice, in supervised context, its polyvalence in basic and interdisciplinary matters. This proposal of Observatory is the constitution of a link of connection and of monitoring between the university, the student and the business fabric in the environment in which the University is inserted. The results obtained with this proposed Observatory of Internships should be noted as a means of analysis that aims to allow the adoption of more effective practices of transition between higher education and the labour market.

This is an observatory still with reduced applicability, with only two years of execution; yet the revealing results are already expressive and very positive. These metrics are amenable to improvement.

The Observatory here explained, in the near future, will contribute to the construction of an observatory to evaluate the trajectories and success in the transition to the Labour Market, of these and the next trainees, once they obtain a bachelor's degree. Downstream from this observatory will be an employment observatory.

\section{REFERENCES}

[1] Comissão Europeia (2014). Modernization of Higher Education in Europe: aConselho Coordenador de Estágioss, retention and employability. Luxembourg: Office of the European Union.

[2] Daniels, J. \& Brooker, J. (2014). Student identity development in higher education: implications for graduate attributes and work-readiness. Educational Research, 56(1), 65-76. doi:10.1080/00131881.2013.874157

[3] García-Aracil, A. \& Velden, R. (2007). Competencies for young European higher education graduates: labour market mismatches and their payoffs. Higher Education, 55(2), 219-239. doi:10.1007/s10734-006-9050-4.

[4] Harvey, L., Moon, S. \& Geall, V. (1997). Graduates' Work: Organisational change and students' attributes. No Title. Birmingham: Centre for Research into Quality and Association of Graduate Recruiters.

[5] Jesus-Silva, N., Medeiros, A. M., Caramelo-Gomes, J.; Costa- Lobo, C. (2016). Quality in higher education: analysis and discussion of evaluative standards internal consistency. Proceedings of ICERI 2016. ISBN: 978-84-617-5895-1

[6] Lent, R. W., Taveira, M. C. \& Costa-Lobo, C. (2012). Two tests of the social cognitive model of well-being in Portuguese college students. Original Research Article. Journal of Vocational Behavior, 80(2), 362-371.

[7] Oliveira, R. \& Costa-Lobo, C. (2015). Skills and well-being at work in it students: transition to employment. HFSP Journal

[8] Taveira, M. C., Faria, L., Araújo, A., Pinto, J. C., Silva, A. D. S. C. S., Costa-Lobo, C., Ferreira, S., Carvalho, M., Konigstedt, M., Gonçalves, S. \& Loureiro, N. (2010). Integração e Bem-estar em Contextos de Trabalho. Braga: APDC Edições. ISBN: 978-989-96700-3-7.

[9] Weible, R. (2009). Are universities reaping the available benefits internship programs offer? Journal of Education for Business, 85(2), 59-63.

[10] Silva, A. D., Costa-Lobo, C., Taveira, M. C., Bernardo, E. \& Bucuto, M. (2010). Academic and life-satisfaction in portuguese and mozambican college students: a comparative study. International Conference of Education, Research and Innovation (ICERI 2010) (pp. 3757-3764). ISBN 978-84- $614-2439-9$.

[11] Brennan, J. \& Little, B. (2006). Towards a strategy for workplace learning. Milton Keynes: Open University Centre for Higher Education Research and Information.

[12] Zhao, H. \& Liden, R. C. (2011). Intership: A recruitment and selection perspective. Journal of Applied Psychology, 96, 221-229. 
[13] Yorke, M. \& Knight, P. (2007). Evidence-informed pedagogy and the enhancement of student employability. Teaching in Higher Education, 12(2), 157-170.

[14] Fugate, M. \& Kinicki, A. J. (2008). A dispositional approach to employability: Development of a measure and test of implications for employee reactions to organizational change. Journal of Occupational and Organizational Psychology, 81, 503-527.

[15] Vieira, D. A. \& Marques, A. P. (2014). Preparados para trabalhar? - Um Estudo com Diplomados do Ensino Superior e Empregadores. Edição: Fórum Estudante e Consórcio Maior Empregabilidade. 